УДК [80 + 82-6] (477) "19"

\title{
LITERARY ENVIRONMENT AND LITERARY SITUATION IN UKRAINE IN 60 - 70'S OF XX CENTURY IN THE CONTEXT OF THE CORRESPONDENCE OF B. ANTONENKO-DAVYDOVYCH
}

\author{
G. P. Kalantaevska, PhD of Philological Sciences, professor assistant \\ N. N. Prokopenko, PhD of Philological Sciences, lecturer \\ S. V. Voropai, PhD of Philological Sciences, professor assistant \\ Sumy State University, \\ Rimskogo-Korsakova Str.,2, Sumy, 40007, Ukraine \\ E-mail: g.kalantaevskaya@journ.sumdu.edu.ua \\ prokopenko3377@gmail.com \\ voropaj@gmail.com
}

https://doi.org/10.21272/Ftrk.2018.10(4)-12

The modern era is marked by confrontation between different ideological and conceptual worlds, which is caused mainly by controversial views on the Ukrainian history and a complicated historical path of the Ukrainian nation to a desired independence. In this struggle, the uncompromising words of the famous Ukrainian writer B. Antonenko-Davydovych sound especially acute.

In the modern conditions, there is a necessity to make effective resistance to the active advent of the imperial ideology of the "Russian world". That is why the study of the opposition of B. AntonenkoDavydovych to russification of Ukrainian society by the totalitarian Soviet system and the destruction of Ukrainian creative intelligentsia in particular in the 60's and 70's of the twentieth century is very important. That is one of the means to protect modern youth from the threat of returning to the atmosphere of contempt and hatred of their native language and culture.

In this context, the article provides a detailed analysis of the writer's correspondence, in which he gave an honest assessment of the literary environment, opportunistic activity of Ukrainian editors and publishing houses, ethical-moral and professional qualities of officials from his environment. B. Antonenko-Davydovych also objectively told the nearest addressees about his struggle with a powerful campaign of Russification of all spheres of Ukrainian social life, about his open performances in the press in defense of his native word, which was forced out from education, science, art, even from the musical sphere.

In the work of many writers, in the planning of the activity of publishing houses, B. AntonenkoDavydovych clearly noticed the signs of serving the interests of party leaders, the policies of the communist regime, revealing the ideological control by security structures, the phenomena of careerism, financial machinations, competition for material benefits and rewards, etc. The brazen imposition of Russian repertoires at the concerts both in Kyiv and villages, falsification of folk art in numerous folklore collections, or intentional discrimination of the Ukrainian word by printing primitive, low-art texts, - nothing of this got past the writer's attention, because of his sensitivity to deception. In most of his colleagues, the writer noted the chronic fear, the willingness to serve the regime, the degradation of creativity, however he also noticed the literary figures of the highest European level.

The denigrating of the honest writer's name that was conditioned by his position regarding the protection of the rights of the Ukrainian language for its full functioning in Ukraine testified to the real threat of assimilation of Ukrainians, which was a continuation of the Valuyev's policy of autocratic Russia.

The study provides an opportunity to realize how dangerous a totalitarian state policy can be. Because it aims to cultivate the mood of fear, anxious expectation, uncertainty among cultural leaders, the dominance of censorship and the hidden propaganda influence of power structures on the activities of editors, publishers, scientific institutions.

B. Antonenko-Davydovych's intransigent position in protecting his native language in an aggressive Russification is a vivid example of the behavior of a patriotic personality, a representative of the cultural and artistic center, which is particularly relevant in our time and allows

(C) Kalantaevska G.P., Prokopenko N. N., Voropai S. V., 2018 
contemporaries to find answers to the challenges of today, in particular regarding the revival of Ukrainian language.

Key words: correspondence, threat of assimilation, ideology of totalitarian system, literary environment, periodicals, Russification of cultural space.

B. Antonenko-Davydovych was often mentioned in a private correspondence about his long-term stay in concentration camps, calling his misfortunes a personal catastrophe, a general mischief, times of peril, a flood, a odyssey, a "distant world", a weightless state, and others like that. Unfortunately, the depressing impressions of captivity, relations with the KGB, surveillance and searches remained a reality. After the official rehabilitation the writer returned to Kiev in 1957, where he intended "after a long forced intermission to fully devote himself to literary work" [1, p. 446], and "return to literature not being dependent disabled person, but - an employee" [1, p. 447], as he wrote in one of the letters to M. Bazhan. He was well aware of the possibility of "deep emotional crisis" associated with the return to the cemetery of his own past.

However, despite the determination to work, home simplicity, worked out for decades patience and a sense of responsibility for the family, B. Antonenko-Davydovych still fundamentally remained at his moral and ethical positions, which he did not intend to yield in any circumstances. His own persuasion eventually became the reason because of which the writer's return to the literary environment of Soviet Ukraine became an extraordinary psychological test for him: troubles with housing, the wary attitude of publishers and editors deprived him of emotional equilibrium, which is necessary for serious creativity. "I screw up in life and cannot find the inner peace that is needed for serious work" [1, p. 464], - B. Antonenko-Davydovych shared his feelings in one of the letters to V. Gzhytsky in December 1957.

It is the correspondence of B. Antonenko-Davydovych that allows the contemporaries to see in the writer the creator of the Ukrainian cultural space in the conditions of a totalitarian regime. He was openly in opposition to communist ideology and "assume more than others: he took courage to play his own role at stake of life - in accordance with their own concepts of duty and dignity" [2, p. 222].

Scientific researches, articles, essays, memoirs of such authors as L. Boiko, I. Kachurovskyi, M. Kotsiubynska, O. Kucheruk, D. Nytchenko, P. Odarchenko, A. Pohribnyi, E. Sverstiuk, and others are devoted to the creative and journalistic work of B. Antonenko-Davydovych, his spiritual figure and place in the cultural life of Ukraine. However, the correspondence of the writer requires more detailed study. It contains a lot of reflections, assessments and characteristics of the literary environment, social tendencies, autobiographical moments, etc. In his letters to relatives and acquaintances, B. AntonenkoDavydovych often referred to the necessity of returning good names to the victims of Stalinist repressions, readily shared the memories of his closest friends-writers and the beginning of his way to literature, explained his own works, mentioned about the attitude of officials to him and so on. However, special attention in the epistolary of B. AntonenkoDavydovych deserves his analysis of the literary life of the 60's and 70's of the XX century under conditions of powerful Russification and assessment of the Ukrainian language in many spheres of cultural and artistic life in one of the Soviet colonies. In those letters, the writer, "as a barometer of his time and his society, is not mistaken in defining many problems and moral diagnoses" [3, p. 146], and this is the relevance of our article, because ethical uncompromisingness and loyalty to national ideals are more than ever needed today.

The purpose of the study is to find out the peculiarities of the views of B. AntonenkoDavydovych on the literary-linguistic situation in Ukraine in the conditions of the strangled, according to E. Sverstiuk, the revival of the sixties. The following tasks should be carried out in order to achieve the goal: to characterize B. Antonenko-Davydovych's perception of the general moral and ethical atmosphere in the environment of writers of the 60 's and 70's of the twentieth century; trace the author's attitudes towards literary officials; to find out the reaction of B. Antonenko-Davydovych to the reprisal against him in the 
periodicals and the prohibition of the printing of his works; outline the writer's impression of the situation with the reduction of the sphere of use of the Ukrainian language and find out the motives of its counteraction to the Russification of the cultural space of Ukraine.

B. Antonenko-Davydovych's letters to V. Pivtoradnia, V. Hzhytskyi, N. Surovtseva, B. Borovyi, Yaryna Holub, and others testify that the writer had no illusions about the real "progress" of literary life under the so-called political thaw of the late 50's. He saw the convincing evidence of this in the advanced articles of the "Literary Newspaper", which, according to him, was a manometer of the force of ideological pressure on Ukrainian culture. In his letters to V. Pivtoradnia, who worked on the true coverage of "the state of things" in the Ukrainian literature of the 20's of the XX century, the writer warned the scientist in October 1957 of the troubles he might have ("... do not jump out first, because the contemporaries are not always honoring "the first brave" [1, pp. 453]). In addition, he shared the observations about the uncertainty, the inconsistency of the sentiments of the official party criticism, which in any way could not assess the Ukrainian literature over the past few decades, and in its surveys showed selectivity, glossing over problems, and traditional accusations. In generally, the literary environment he got in after returning from concentration camps shocked B. Antonenko-Davydovych, because there, in spite of the proclaimed changes in party politics, the atmosphere of fear prevailed as before. The younger generation of writers and critics mostly was afraid to speak openly not to strike the same tone of the officials' instructions from culture and ideology. B. AntonenkoDavydovych states in his letters that in the literary circles there were the mood of anxious expectation and uncertainty. He observes the fear that deeply rooted in the subconscious of contemporaries. "After the terrible mowing, where we were only casual mistakes, the wretched secondary grass grew," - the writer shared his observations with V. Hzhytskyi in October 1957. "I am still struck by the fright that I encounter here at every step in those people who were once quite normal. It seems to me that many of them were scared during the years of trouble for a lifetime. Now, when the circumstances are completely different, they do not know what to stoop and be good at every step to reinsure themselves" [1, p. 462]. In a letter to the same addressee, the writer continues to assess the situation: "... today no one really knows what they are allowed or not allowed to do, and what will be free tomorrow" [1, p. 462-463].

B. Antonenko-Davydovych's impressions of the Congres of Writers, which he wittily described in letters to his daughter Yaryna (congress of 1966) and N. Surovtseva (Congress of 1976) indicatively characterized the literary life of the late 60's. Telling in particular about the congress of 1966 , the author of the letter emphasizes the serious preparation for it of official ideological institutions. All possible measures were used, "so that the congress passed in terms of the empty useless parade ... so that, God forbid, did not allow the national matter with its pity, complaints and hopes to raise in the speeches, for which nothing to answer" [1, p. 490]. Because everyone had faced "a sad practice of the brutal manifestations of the great power and the leveling of national cultures and languages" [1, p. 490-491]. However to writer's satisfaction, "the national element broke through" and forced even cautious critics to talk about "tactless and the great-powerness of Russian linguists..." In the journal "Linguistics», they somehow published an article on the prospects for the development of the languages of the peoples of the USSR, diplomatically kept silent about the Ukrainian and Belarusian languages. Because to refuse to them in the prospects of development would be desirable, but dangerous, however the political concepts of those linguists did not include the recognition the rights of the Ukrainian and Belarusian languages to development" [1, p. 491]. According to B. AntonenkoDavydovych's letter, the language matter appeared to be extremely relevant for the guests of the congress from Georgia, Uzbekistan, Lithuania and other republics, because they all openly declared that the Russian language was dominant in the national schools. Under the pressure of "general heat" even the Russian representatives acknowledged the facts of assimilation, but the author of the letter draws attention to their phrase "we moved too fast", 
which testified to the condemnation of not the Russification itself, but only its leisurely pace.

Despite the emotional statements of the participants of the congress, B. AntonenkoDavydovych saw the creative atmosphere as provincial and timid. "It was difficult to write something, but to publish something worthwhile became even more difficult" [1, p. 493], - he wrote to his daughter Yaryna in February 1967. The writer was indignant by the tendency to send from the Central Committee of the Komsomol and the party of deputy editors of literary journals, who were supposed to watch the "safety" of printed materials. One of his own stories was "killed" by such a deputy, who self-confidently motivated the failure to the fact that in the work "the revolution was shown somehow spontaneously, without the leading role of the party" [1, p. 496]. According to B. Antonenko-Davydovych's observations, such a phenomenon became massive: "In general, now there's a fashion to send to the editorial staff and publishing houses of such overseers, so that "something did not happen" suddenly. In general, this jubilee year (the fiftieth anniversary of the revolution - G.K.) - is very difficult for literature, because nobody knows what can and cannot be, and just in case everyone insures themselves" [1, p. 496]. The situation did not improve even later, when the author of the letters intended to celebrate his own seventy-year jubilee in 1969. For the leadership of the Writers' Union, this event would have caused too many troubles, because it would be impossible to control the jubilee evening of B. AntonenkoDavydovych. To his opinion, officials were afraid that his fans would not behave according to the script. This unpredictability frightened the most "professional guards", according to E. Sverstiuk's definition. He mentioned that B. Antonenko-Davydovych even in everyday life, in his own house cultivate the truth and sincerity, unified the cultural environment around him: "This is his fault according to the degree of freedom of the 60's and 70's: an open house in a closed society!" [2, p. 223]. As B. Antonenko-Davydovych understood the true cause of the passivity of the leaders of the Union, he commented on it in a letter to his daughter in October 1969: "Earlier you asked me to write to you when my jubilee evening in the Union would be. I still do not know when. It is very possible that and never. I feel the current leadership of the Union under the influence of other higher authorities is afraid of such an evening. Many people can come, and this can already be regarded as a certain demonstration; and secondly, they can organize the "right" greetings, but they cannot predict what the jubilee will say in his last word, because he always speak his mind" [1, p. 508-509].

Sometimes in the letters to Yaryna Holub, B. Antonenko-Davydovych mentions domina in periodicals on jubilee topics, about the deliberate silence in the editions of his books at a time when positive reviews appeared on them in the Moscow journals. Such a situation developed in 1970 with the book "From afar and near". The book was given a positive review by the magazine "The matter of Literature", also by the radio station "Freedom", but "... everything was silent in Ukraine," because it was prosperous "in opportunistic and insincere critical articles and reviews" [1, p. 517]. B. Antonenko-Davydovych continues his own opinion on the biased attitude towards Kyiv literary officials in the same letter of September 5, 1970. He writes, "It cannot be said that nobody here wanted to respond to this book. I know about one such attempt, and there were probably more of them, but the zealous editors, either showing the initiative from below, or obeying the informal instructions from the top, given by the secondary apparatus of the Central Committee of the CPU, said to the other authors, "Well, why inflate the writings of A.-D. and popularize it! Let him be pleased with the fact of printing his book" [1, p. 517].

Party ideologists-guards could not accept the uncompromising position of B. Antonenko-Davydovych as to protection of the Ukrainian language, with its influence on young people, when "communication with him... disinfected the world outlook, and strengthened the civil conscience" [4, p. 627]. The condition of the Ukrainian language, and hence the literature of the early 70's of the twentieth century, was well described by I. Dziuba. He said, "... from the second half of the 1960's, after the arrests of 1965, which marked the new peak of the struggle against "Ukrainian bourgeois nationalism", the party 
supervision over the Ukrainian language (not only over its functional sphere, but also over its vocabulary and style) acquired pathological character. Everything was doing in order to deprive the Ukrainian language of any originality and to bring it to the Russian language as close as possible, and then it would become completely unnecessary as a variation of the Russian, and would vanish by itself. In the context of the large-scale process of "convergence", and then the "fusion" of socialist nations, this was supposed to be the final stage of Russification. The state contraction of the sphere of use of the Ukrainian language was supplemented by "cleansing" it [5, p. 790]. B. Antonenko-Davydovych's books "What and How" (1962), "In Literature and about Literature" (1964), "As We Speak" (1970), and his articles in periodicals resisted such a powerful attack. In addition, the writer "had the courage to appeal to the Minister of Education of Ukraine, Udovychenko with a letter in which he ...sharply criticized the Minister of Education for his lack of knowledge of the Ukrainian language". In his letter the writer said, "It's terrible to think that the Minister of Education himself, from whose language the teachers and students must learn, speaks surzhyk! This is an unprecedented incident not only in the republics of the Soviet Union, but in the whole civilized world." This letter was a response to Udovychenko's speech on television" [6, p. 369 - 370]. The literary critic I. Kachurovskyi while mentioning B. Antonenko-Davydovych's book "From afar and close" (1969), which was devoted to Ukrainian writers of various eras, noted that in such conditions it was a great courage to quote the Valuev circular of 1863 (as the author did), because the comments to it already corresponded with the Soviet prosecution of the Ukrainian language. "How it suits the then Ukrainian reality" [7, p. 314].

However, the writer had literally to hide some of his writings from periodic searches, as, for example, happened to a series of stories, which was later called "Siberian stories". He wrote about the novel "Everything May Be", which he just finished, to his daughter Yarin, in a letter dated July 18, 1971. "I want to give it to you not only for acquaintance but also for preservation, but I could do it only when I meet with you" [1, p. 525].

B. Antonenko-Davydovych characterizes the situation with fiction in 1971, as not only unfavorable to creativity, but also threatening the writer's personality. He said, "... in the literary life there is a stagnation and stuffiness now, that I feel unhappy and there is no reason to hope for some kind of change in the near future, in this arid climate of literature" [1, p. 525].

B. Antonenko-Davydovych noted in a letter to N. Surovtseva in April 1971, that the tragic tendencies towards the transformation of the Ukrainian language into a "macaroni mixture" were already quite noticeable in 1957, when after returning from a long "journey" he, in his words, began to clean up the Augustinian stables of speech chaos. The writer was indignant by the position of "our linguists," who "did not do what was supposed to be, and sometimes they did something that only discredited our language, cut it off from the folk root, but approached the fraternal Russian language..." [1, p. 470]. In the writer's opinion, there were "corrupt souls about which Taras Shevchenko once angrily spoke, "sold for a piece of rotten sausage" [1, p. 470]. Anonymously, or hide behind the names of others, the leaders of the Institute of Linguistics in their articles-refusals responded to B. AntonenkoDavydovych's resonant linguistic works. They stated that letter " $r$ " is unnecessary for the Ukrainian alphabet (the article "There is nothing to moan"), but the writer reasonably defended the necessity of its returning ("The letter for which to moan"). Yu. Sherekh mentioned this dramatic situation in his work "that's how we were taught the correct pronunciation". He wrote, "Before 1905, the Russian government also banned the usage of letter " ". This was part of the prohibition of peculiarities in the Ukrainian alphabet with the replacement, as it were said, with Russian "jarizhka". B. Antonenko-Davydovych's article about the letter " $\Gamma$ " clearly evokes anxiety. The matters of Russification of the Ukrainian language are not subject to public discussion. This is typical of recent years, that the measures in this direction are used secretly." [8, p. 218]. Harassment of the writer by linguists-assimilators caused the incident that B. Antonenko-Davydovych's book, "As We Speak," instead of being issued with a circulation of 65,000 copies, appeared in a 
circulation of only 15,000 . The reader received less than a fourth part of it. Such a "linguistic-literary" environment often showed aggression to an elderly writer who was burdened with personal problems, and this was accompanied by humiliating charges. It was 1973, a time that was carefully described in the diary by O. Honchar. In a note on May 9 that year, a former mortar warrior said, "The atmosphere is oppressive, hard to breathe for many. In the 45th, it seemed that a person has reached its top and there is no place for evil, the future filled with the sun... However, the battle continues. In other forms, however, it is the same persistent, irreconcilable... Some black lists are walking in the editions, publishing houses. Do not print it, do not mention it..." [9, p. 147-148]. Two months later, another note appeared, - "The palace "Ukraine". Presentation of the Medal of Friendship of Peoples to the Ukrainian republic. At all celebrations, none Ukrainian word! I should say... it is friendship!" [9, p. 154]. Under these circumstances, on July 13, 1973, the pages of the "Literary Ukraine" contained material titled "In the role of the beggar". This material in Komsomol lexical-stylistic manner tells about B. Antonenko-Davydovych's foreign relations as if they existed, described his "wonderful financial situation", and made public the private information about his son. With shocking pretentious brutality the author of the article, ("the laureate of the Republican Prize to them. Ya. Halan"), blamed B. AntonenkoDavydovych for anti-Sovietism, nationalism, and inappropriate education of his own son. Referring to the criminal case, the "laureate" was indignant that B. Antonenko-Davydovych listened to "exactly those foreign radio stations, which most of all tells lies about all the Soviet, denigrate the heroic work of our people, which do not spare bright colors to describe capitalist paradise" [10, p. 4]. The author of the open denunciation also reminded of the links between B. Antonenko-Davydovych and the dissidents. He wrote, "During the trial of V. Moroz, it turned out that when compiling some opuses of nationalistic content, one of his advisers was B. Antonenko-Davydovych. About the ideological false influence of this "confessor" on some young writers was written once in the press" [10, p. 4].

B. Antonenko-Davydovych replied to the libel of the journalist-laureate. He wrote about his reaction and its consequences in a letter to his daughter Yaryna in October 1973. "September 4, I had an acute (mainly from my side) conversation in the Union of Writers of Ukraine, which was a result of my statement-protest on the article published in July. I have stayed in my positions of dignity, expressing my indignation against the lie against me. Since in my words there was no shadow of repentance, as the situation requires, my case was postponed for an indefinite time, that is, it was shut down... If earlier I complained about the lack of criticism regarding my person, now I am satisfied with the present silence, because for now I cannot hope for more" [1, p. 534-535]. A year later, in August 1974, B. Antonenko-Davydovych shared with his daughter his thoughts on the relationship with the detractors in the context of his own 75th anniversary, noting a large number of congratulations from friends and readers, even from Poland and Australia, where his books came out, with the exception of "official greetings" from literary officials. In this cautious indifference, he found some kind of disappointment. "But it seems that the persecution of me in the press stopped, as it was last year... There's a possibility that a certain mighty ruler gave instructions to stop persecuting me" [1, p. 539].

B. Antonenko-Davydovych in a letter to V. Sirenko, N. Surovtseva, Yaryna Holub, and other addressees spoke about the merciless extrusion of the Ukrainian language from the educational, cultural and artistic spheres in the mid-1970s. In particular, the writer informed V. Sirenko about the repressions against the Ukrainian language in Vatchin (in honor of the name of the party leader of the Dnipropetrovsk region). He wrote about "Vatchinski achievements in the area of the final solution of the national question", "in Dnipropetrovsk there is no Ukrainian school, the Yavornytskyi museum is already 1,5 years under repair, and how much it will be - is unknown. Even Ukrainian signboards after the repair of government buildings disappear, only the Russian ones are left" [1, p. 656]. B. AntonenkoDavydovych writes with indignation that even the amateur rural groups must perform only in Russian. Moreover, there is control that there are enough Russian songs on the concerts, even in the kolkhozes in the villages, all the inscriptions - only in Russian. Summing up the 
general picture, the writer notes, "...it can be said that to act this way is more honest (because the direction, which was well-known from the beginning is immediately visible) than, for the same purpose, use Ukrainian camouflages... But this way everything is clear" $[1$, p. 656]. In the same letter, he calls ironically the change in the name of a cafe on Lenin's street from " Khvylynka to " Minutka" (both means "minute" - G. K.) a remarkable achievement of Ukrainian culture. According to the author, here obviously, "without the intervention of our deputies of the Supreme Soviet of the Ukrainian SSR type Stelmakh or Honchar, who, passing daily "Minutka", at last did not stand and, as you see, reached their goal! Now we all have something to be proud of!" [1, p. 656]. B. Antonenko-Davydovych in a letter to V. Sirenko of June 30, 1976, admitted with regret, "in Chernihiv before the war there was one Russian school, the other schools were Ukrainian; and now there is only one Ukrainian school, and the rest are Russian... This is our further development of the Ukrainian culture or rather the Ukrainian part of the Soviet culture" [1, p. 659].

B. Antonenko-Davydovych sharply and wittily described the situation with literature and language in a letter to N. Surovtseva after the writer's congress in 1976, to which he himself was not invited even as a guest. Admitted that despite of the boring four-hour report by the head of the Union of Writers of Ukraine, which covered the topic of the rapid development of literature, "the sensible skeptics, who are able to follow more carefully the periodicals and separate books than I, say that there is no literature as there was no before, and it is unlikely she can appear in today's conditions" [1, p. 473]. Because the wise writers argue that their work "deserves a proper honor", while those involved in the management of the literary fund are urgently assigned to other responsible positions through the so-called "violation of financial discipline". B. Antonenko-Davydovych ironically notes that in the sphere of the same nearby-literary life, that is even more interesting, the "petty intrigues" continues - a fierce competition for space in publishing plans, for material support, awards, vouchers, posts - in short, for the space for "grazing ". The writer notes that the punishment for stealing public money - this is mainly the appointment of a deputy editor-in-chief of the famous journal or a teacher to the university, because "we need someone to raise our upcoming generation in the proper moral direction" [1, p. 473].

Russification, according to observations of B. Antonenko-Davydovych, deeply penetrated into the professional musical sphere. Always remembering about "the men, who by their official duty should be interested in someone else's correspondence" [1, p. 477], in a letter to N. Surovtseva from September 10, 1976, he mocked the television concert of Ukrainian chapel of bandura players. "At that concert those incomparable masters sang four of six acts of the program to the accompaniment of banduras in Russian, and in two Ukrainian songs they gave their respect to the Party". I was so fascinated by those Russian numbers and the Russian language emcee that I myself wanted to start singing: "Ah, you son of a bitch, a Kamarin man!", But unfortunately, I have long lost my bass..." [1, p. 478]. B. Antonenko-Davydovych continues the story about "the further development of Ukrainian culture," in a letter to N. Surovtseva, written in October 1976. He wrote, "In this regard, new measures are now visible - to make our culture understandable for everyone, not just for people like us, at all Ukrainian concerts the emcee speaks only in a comprehensible language, spreading the range of influence of our culture" [1, p. 481].

As evidenced by one of the letters to N. Surovtseva in April 1977, an absurd manifestation of the offensive against the Ukrainian language reached its peak in March, during the honoring of the memory of Shevchenko. B. Antonenko-Davydovych in his letter described the wreath-laying procedure at the monument to the poet in March 9, and his participation in this procedure. He noted about the event: "At the invitation of the young people I came down to the pedestal and with them sang "Testament (Zapovit)" with my senile voice. It was nice to see a wreath from our literary theorists there who forgot the words of Taras "Learn, my brothers..." On this wreath was a very eloquent inscription: "for T. G. Shevchenko from the Institute of Literature" [1, p. 483]. In his letters, B. AntonenkoDavydovych repeatedly mentioned an unofficial ban on singing "Testament (Zapovit)" of Shevchenko, because people, listening to it, stood up at concerts. 
B. Antonenko-Davydovych's his opinion on the various collections of works of folk art, which were published in the 70s, attracts attention. These works offered readers "folk" dumas under the titles "About the army of red, about Lenin-father and his loyal sons" [11, p. 127]. "...in contemporary, at least Ukrainian folk literature, which is currently being published, it is simply falsified. Not very clever poems of rural obscure poet posed as folklore, and the only criterion of suitability was the political correctness of stupid writings." [1, p. 546]. The write also reminds us of mass extermination a number of famous works even from "full editions" of many masters of the word, including T. Shevchenko. In one of the letters to Yaryna Holub, dated 1979, B. Antonenko-Davydovych with bitterness tells about the dirty corruption cases that took place at the presidium of the Union of Writers of Ukraine on its leaders, on the financial operations of cheaters and careerists. One of them, holding the post of head of the Ukrainian culture in the Central Committee of the Communist Party of Ukraine, "Ukrainophobe by nature, not only did not care for the further development of Soviet culture, but in every way slowed it, allowing only the demonstration of what could compromise our culture" [1, p. 556]. Writing about the moral qualities of the staff of the newspaper "Literary Ukraine" and the publishing house "Soviet writer" B. Antonenko-Davydovych notes that the editorial staff received fees for "data about radio programs or the publication of new books" [1, p. 557], and for "editing" the works of I. Kotliarevskyi or T. Shevchenko. Sometimes due to internal conflicts, "their dirty affairs come up. For example, it turned out that the staff of "Literary Ukraine", of 26 people, informed different authorities on each other!.." It would be correct to judge these scoundrels, but the officials only take them out of their high positions, because they are afraid that further logical consequences could discredit the party, in which the culprits remain members" [1, p. 557-558].

In his letters B. Antonenko-Davydovych described 70-80's of XX century as a dark period when the totalitarian system was more ready, according to O. Hertsen, to forgive the "population" theft and bribes, murder and robbery than insolence to have human dignity and audacity of an independent word" [12, p. 253]. However, the true literature still existed and did not escape the sharp eye of B. Antonenko-Davydovych, who also followed the Russian novelties. Among works worthy of attention, he calls the novels of V. Bykov "The Dead is not hurting", Ch. Aitmatov "Farewell, Gulsari!", publications in the journal "New World". He advise to his daughter Yaryna to read such writers as Tryfonov, Rasputin, Shukshyn, and others. He also commends in a letter dated November 26, 1976, that such talented works could not, under any circumstances, be published" in our Ukrainian conditions. Someone, who is hostile but intelligent, allows you to print only any trivial things in order to have a reason to say, "You see, what this literature is and culture in general? Indeed, even the Ukrainians themselves refuse to read it!" [1, p. 542].

Among the most brilliant creative figures of the 60's and 70's B. AntonenkoDavydovych calls Lina Kostenko, whose name he most often and emotionally mentions in the letters to many recipients. In addition, he mentions the names of Hryhir Tiutiunnyk, A. Dimarov, Ye. Hutsalo, R. Ivannychuk, Yu. Mushketyk, V. Symonenko, O. Honchar, and other authors, sometimes recalling their personal creative drama. For example, in August 1976, he wrote a letter to his daughter about the latest works by Ye. Hutsalo: "...what the forced and useless things appear now from under his once talented pen!" [1, p.542]. B. Antonenko-Davydovych appreciated the poetic collection of Lina Kostenko "Uniqueness", a novel in the poems "Marusia Churai", and other her works. According to him, "this is truly the most talented poet of our time, which is not equal to many authors... The truth, sincerity without regard, aphorism, and deep subtext, lift her up above the dullness and the colorlessness of those countless works, which are gathering dust on the shelves of bookstores and libraries... Imagine how this literature would glow, if such talented creators as Lina Kostenko were not slowed down and under pressure..." [1, p. 568]. B. Antonenko-Davydovych's attention to talented literature is most clearly attested to by his letter to P. Kravchuk of April 30, 1969. In the letter he advises to read O. Apanovych's book "The Armed Forces of Ukraine", the novel by R. Ivannychuk "Malvy" ("the best thing 
that came out in our literature over the past year" [1, pp. 613]), the novel by I. Muratov "Confession on the top", the novel "Zinskoy puppy" by A. Dimarov. B. AntonenkoDavydovych approved "Ukraine is our Soviet" by P. Shelest despite the author's high party position: "The book is very interesting; besides, there is a lot of comforting parts for the Ukrainian reader, such as those about the Cossacks and its historical significance. It is said, that the Ukrainian art was in debt to Cossacks, because it did not glory it enough. The proper assessment of Peter I's work in relation to Ukraine was given in the book, and the cult of Stalin's personality was mentioned..." [1, p. 623]. A lot of attention was paid by B. Antonenko-Davydovych to the review of the literary environment in Ukraine. In the letters to D. Nytchenko to Australia (which, however, do not have such an emotionality and to a certain degree of openness as letters to addressees in Ukraine) the writer mentioned the Writers Congress in 1971, "You read about the Congress of Writers in "Literary Ukraine", and it is hardly possible to say more about it in the context of our correspondence" [13, p. 55]. In an effort to share the best Ukrainian books, B. Antonenko-Davydovych systematically sent abroad literary novelties and valuable editions that appeared in the bookshops, and which were not easy to buy (unfortunately, not all addressees received them). Thus, in a letter dated Aug. 2, 1971, he wondered if D. Nytchenko had received the "Chronicle of Samovydsy", which was instantly sold out in Kyiv, and he doubts that the "History of Rus", published in Australia, will not be lost "in such a distant road from another continent" [13, p. 57], inserting clear subtext into these words. The letters to the scientist and journalist are replete with warm memories about S. Vasylchenko, H. Khotkevych, M. Zerov, M. Khvylovyi, O. Biletskyi, other well-known cultural figures, who B. Antonenko-Davydovych was personally acquainted with, when he was young. The frequent mention in the letters of the Ukrainian traveler M. Miklukho-Maklai, whose figure was so interesting to D. Nytchenko attracts attention. Having visited New Guinea, he wrote an essay "Follow the Miklukh-Maclay" and sent it to B. Antonenko-Davydovych. The essay made a strong impression on the writer. It caused a number of questions, in particular, the linguastic question. He wrote, "I am very interested in the linguistic question in the now independent New Guinea - how does the central government act among that "Tower of Babel" of languages and dialects? Is there surzhyk from Papuan-English linguistic mix can help? On the other hand, maybe the language is not the main component in the creation of a single liberated nation? This point of view is inspired by the practice of some Negro states, and, it seems, India, which has plenty of dialects and no single national language, but is striving to establish its own state. By the way, I accidentally came across a man in Kiev, who forgot how to speak Ukrainian, but in the conversation he appeared to be a great patriot of his land..." [13, p. 162].

Consequently, B. Antonenko-Davydovych's close attention to the literary process and linguistic situation in Ukraine in the 60's and 70's of the XX century gave him the opportunity to discover and assess, on his own experience, the legitimate tendencies for the Soviet totalitarian regime. They were the tendencies to control the ideological and security structures of the state over the cultural and artistic, and spiritual life of society, the selection of creative people by means of intimidation, blackmail, deprivation of the opportunity to be printed, moral pressure, etc. The writer noted that fear, uncertainty, anxious expectations are prevailing in the literary environment of that time. Along with this, there existed the self-confidence of the leaders who, at editions, publishing houses and scientific institutions, engaged in fraud and followed informal guidelines to promote the convergence of cultures and languages in the context of the course for full assimilation and the merger of the Ukrainian nation with Russian. Without the opportunity to be printed, B. AntonenkoDavydovych, contrary to the expectations of ideological curators, showed obstinacy in the proposed compromises, made every possible effort to protect his mother tongue in conditions of aggressive Russification. 


\section{ЛІТЕРАТУРНЕ СЕРЕДОВИЩЕ ТА МОВНА СИТУАЦІЯ В УКРАЇНІ 60 - 70-Х РОКІВ ХХ СТОЛІТТЯ В КОНТЕКСТІ ЛИСТУВАННЯ Б. АНТОНЕНКА-ДАВИДОВИЧА}

Г. П. Калантаєвська, канд. філол. наук, дочент,

Н. М. Прокопенко, канд. філол. наук, викладач,

С. В. Воропай, канд. філол. наук, дочент

Сумський державний університет,

вул. Римського-Корсакова, 2, м. Суми, 40007, Украӥна

E-mail: g.kalantaevskaya@journ.sumdu.edu.ua

prokopenko3377@gmail.com

voropaj@gmail.com

Сучасна епоха позначена протистоянням між різними ідеологічними та концептуальними світами що спричинене, в периу чергу, протирічними поглядами на наму історію, складним історичним поступом української начії до омріяної незалежності. У иій боротьбі особливо гостро звучить сьогодні безкомпромісне слово відомого українського письменника Б. Антоненка-Давидовича.

В умовах необхідності чинити дієвий опір активному наступові імперської ідеології "русского мира» дослідження протидії Б. Антоненка-Давидовича зросійщенню тоталітарною радянською системою украӥнського суспільства загалом і знищенню його творчої інтелігениї зокрема в 60-х - 70-х роках ХХ століття є одним із засобів захистити сучасну молодь від загрози повернення в атмосферу зневаги ненависті до рідної мови і культури. У такому контексті у статті здійснено детальний аналіз листування письменника, в якому він дав чесну оцінку літературному середовищу, кон'юнктурній діяльності українських редакцій $і$ видавництв, етико-моральним та професійним якостям чиновників із письменницького середовища, а також об'єктивно розповів найближчим адресатам про особисту боротьбу із потужною кампанією русифікаиії всіх сфер украӥнського суспільного жсття, про своі відкриті виступи у пресі на захист рідного слова, яке твалтовно витискалось із освіти, науки, мистецтва, навіть із музичної сфери.

У творчості багатьох письменників, у плануванні діяльності видавництв Б. Антоненко-Давидович добре помічав переважно ознаки обслуговування інтересів партійних керівників, політики комуністичного режиму, вияви ідеологічного контролю безпекових структур, явища кар'єризму, фінансових махінацій, конкуренції за матеріальні вигоди та нагороди тощо. Повз увагу чутливого до фальші письменника не пройшли нахабне нав'язування російських репертуарів на конщертах як у Києві, так $i$ по селах, фальсифікація народної творчості у численних фольклорних збірках чи зумисна дискриміначія украӥнського слова шляхом друкування примітивних, низькохудожніх текстів. У більшості своїх колег письменник відзначав хронічний переляк, готовність прислужувати режимові, деградацію творчості, проте помічав і літературні постаті найвищого європейського рівня.

Шельмування чесного імені письменника, зумовлене його позицією щодо захисту прав украӥнської мови на повноцінне функиіонування в Україні, свідчило про реальну загрозу асиміляиії українців, щчо було продовженням валуєвської політики самодержавної Росії.

Дослідження дає можливість зрозуміти та усвідомити, наскільки небезпечною може бути політика тоталітарної держави, спрямована на культивування настроїв страху, тривожного очікування невпевненості серед діячів культури, домінування цензури та прихованого пропагандистського впливу владних структур на діяльність редакцій, видавництв, наукових установ.

Непримирима позичія Б. Антоненка-Давидовича в питаннях захисту рідної мови в умовах агресивноі русифікаиї є яскравим прикладом поведінки патріотично налаштованої особистості, представника культурно-мистецького осередку, що особливо актуально в наш час і дозволяє сучасникам знайти відповіді на складні виклики сьогодення, зокрема щодо відродження украӥнського слова.

Ключові слова: епістолярій, загроза асиміляиії, ідеологія тоталітарної системи, літературне середовище, періодика, русифікачія культурного простору.

\section{REFERENCES}

1. Antonenko-Davy`dovy`ch B. Great-grandfathers' descendants. Kyiv: Publishing House “Ky`yevoMogy`lyans`ka akademiya”, 1998. 696 p

2. Sverstyuk Ye. Faithful until the end. Prodigal sons of Ukraine. Kyiv : Association "Znannya" of Ukraine, 1993. $256 \mathrm{p}$.

3. Kalantayevs`ka G. P. Psychological portrait of contemporary and society in the book of reports of B. Antonenko-Davy'dovy`ch “Ukrainian Land” . Filologichni traktaty. 2013. Vol. 5, № 2. P. 145 - 152. URL: http://tractatus.sumdu.edu.ua/en/kalantayevska-g-p-dubinina-m-o-psihologichniy-portret-suchasnika-isuspilstva-u-knizi-reportazhiv-b-antonenka-davidovicha-zemleyu-ukrayinskoyu/

4. Sambros Yu. Correspondence with B. Antonenko-Davydovych. Antonenko-Davy`dovy`ch B. In 2 v. Kyiv : Naukova dumka, 1999. Vol. 2. 656 p.

5. Dzyuba I. Magician of the Ukrainian word (M. Lukash). From the well of the years : In 3 v. Kyiv : Publishing House "Ky`yevo-Mogy`lyans`ka akademiya”, 2006 - 2007. Vol. 3. 880 p.

6. Odarchenko P. Russification of Ukraine and struggle for the salvation of the Ukrainian nation. Ukrainian literature. Collection of selected articles. Kyiv : Smolosky`p, 1995. 407 p. 
7. Kachurovs 'ky j I. From "Death" - to immortality. Boris Antonenko-Davydovych and his workouts in the retrospective of the time. Radiant sylvetas: Lectures, papers, articles, essays and research. Kyiv : Publishing House "Ky`yevo-Mogy`lyans`ka akademiya", 2008. 766 p.

8. Sherex Yu. So we were taught the correct pronunciation. Triptych about language. Rapids and Zaporizhzhia. Literature. Art. Ideologies : In 3 v. Kharkiv: Folio, 1998. Vol. 3. 431 p.

9. Gonchar O. T. Diaries : in 3 v. : Vol. 2 (1968-1983). Kyiv: Veselka, 2008. 607 p.

10. Podolyan M. As a beggar. Literaturna Ukrayina. 1973, 13 July.

11. Folk dumas, songs, ballads. Kyiv : Molod, 1970. 335 p.

12. Gercen A. Y. Past and thoughts. Kyiv : Dnipro, 1976. 268 p.

13. Ny`tchenko D. 200 letters of B. Antonenko-Davydovych. Mel'born : Publishing House "Lastivka" Ukrainian writers' association "Slovo", 1986. 272 p.

\section{СПИСОК ВИКОРИСТАНИХ ДЖЕРЕЛ}

1. Антоненко-Давидович Б. Нащадки прадідів / Б. Антоненко-Давидович. - К. : Видавничий дім «КМ Academia», 1998. - 696 c.

2. Сверстюк Є. Вірний до кінця / С. Сверстюк // Блудні сини України. - К. : Товариство «Знання» України, 1993. - 256 с.

3. Калантаєвська Г. П. Психологічний портрет сучасника і суспільства у книзі репортажів Б. АнтоненкаДавидовича «Землею українською» / Г. П. Калантаєвська // Філологічні трактати. Науковий журнал. Суми, Сумський державний університет, Харків, Харківський національний університет імені В. Н. Каразіна. - 2013. - Т. 5. - № 2. - C. 145 - 152. - URL: http://tractatus.sumdu.edu.ua/en/kalantayevska-g-pdubinina-m-o-psihologichniy-portret-suchasnika-i-suspilstva-u-knizi-reportazhiv-b-antonenka-davidovichazemleyu-ukrayinskoyu/

4. Самброс Ю. Листування 3 Б. Антоненком-Давидовичем / Ю. Самброс // Антоненко-Давидович Б. Твори : В 2 т. - К. : Наукова думка, 1999. - Т. 2. - 656 с.

5. Дзюба І. Чаклун-характерник українського слова (М. Лукаш) / І. Дзюба // 3 криниці літ : У 3 т. - К. : Видавничий дім «Києво-Могилянська академія», $2006-2007 .-$ Т. 3. - 880 с.

6. Одарченко П. Русифікація України і боротьба за рятування української нації / П. Одарченко // Українська література. Збірник вибраних статей. - К. : Смолоскип, 1995. - 407 с.

7. Качуровський I. Від «Смерти» - в безсмертя. Борис Антоненко-Давидович та його доробок у ретроспекції часу / І. Качуровський // Променисті сильвети : Лекції, доповіді, статті, есеї, розвідки. К. : Видавничий дім «Києво-Могилянська академія», 2008. - 766 с.

8. Шерех Ю. Так нас навчали правильних проізношеній. Триптих про мову / Ю. Шерех //Пороги $\mathrm{i}$ Запоріжжя. Література. Мистецтво. Ідеології : У 3 т. - Харків: Фоліо, 1998. - Т. 3. - 431 с.

9. Гончар О. Т. Щоденники: У 3 т. : Т. 2 (1968 - 1983)/ О. Т. Гончар. - К. : Веселка, 2008. - 607 с.

10. Подолян М. В ролі жебрака / М. Подолян // Літературна Україна. - 1973, 13 липня.

11. Народні думи, пісні, балади. - К. : Молодь, 1970. - 335 с.

12. Герцен А. И. Былое и думы / А. И. Герцен. - К. : Дніпро, 1976. - 268 с.

13. Нитченко Д. 200 листів Б. Антоненка-Давидовича / Д. Нитченко (Чуб Д.). - Мельборн : видавництво «Ластівка» об'єднання українських письменників «Слово», 1986. - 272 с.

Надійшла до редакиії 8 вересня 2018 р. 